\title{
EFP Regimen
}

National Cancer Institute

\section{Source}

National Cancer Institute. EFP Regimen. NCI Thesaurus. Code C9688.

A chemotherapy regimen consisting of cisplatin, etoposide, and fluorouracil that may be used in the treatment of non-small cell lung cancer (NSCLC). 